\title{
Educated Working Mothers to Hoist Children Academic Performance
}

\author{
Nargis Ara \\ Government Girls Postgraduate college, Saidu Sharif, Swat Pakistan
}

\begin{abstract}
It is a universal truth that education and work of mothers is an important input for the progress of an individual, society and nation. Mothers' education and work give adequate knowledge, provides essential skills and develops desirable attitude to achieve high academic performance of their children. Objectives of study were (1) to investigate the impact of educated working mother and educated non working on the academic performance of her children. (2) To investigate the perceptions of mothers about her children's academic performance. (3) To compare the academic results of children of working mothers with that of the children of non-working mothers. Total private public schools in Saidu Sharif were 15 and total numbers of students were 358. Stratified random sampling technique was used and 140 students of both mothers were taken as a sample. Besides that, one 140 mothers of selected students were also the part of the sample. Questionnaires were based on Lickert Scale. The academic results were also collected from the school administration. This study might also be important for educated working people how they could enhance learning outcomes of their children in classroom. Children of working mothers had higher mean score than the children of nonworking mothers means score.
\end{abstract}

\section{Introduction}

"Education means the process of getting knowledge, developing the sources of knowledge and enhanced reasoning power which improve the qualities of prospective citizen of the society". [1] The first determinant, which is the first and most important bed to nurture children, is the mother education. Mostly new mothers do not always experience immediately in mother love and emotions with her children. Learning is gradually unfolding experiences with passage of time that can take hours, days, weeks, or possibly will take months or years to develop in a child. Mother feels and takes the pains of her children for ages and always busy in lifelong struggles and strives to help, to survive the major population of the world. Academic achievements and performance of children is the integration of social interaction, facilitation by parents and assistance of better educational institution. Academic performance means educational learning and achievement in schools, colleges and universities to get certain scores, grades, ranks and promotion to next class and to get job in future for livelihood. According to [2] Those mothers who are high educated and working are more sensitive to their children. They focused on the point that "parents should provide attentive hands-on care to their children."

Parents specially with university education, (except fathers with a university diploma) spend well over an hour a day more caring for children than do parents with no education". Education pushes mother more actively toward work and takes care of child to improve learning.

[3] view states "learning is more or less permanent incremental modification of behavior which results from activity, special training, or observation”. Contemporary educated mother means a mother of the present day, up dated, recent and modern educated woman. According to the old concept of education an educated mother can make an educated nation. An educated mother is source of development and a unit of prosperity. More educated mother creates more and more educated population.

Educated working mother irrespective of race, religion, culture, region and heritage is under the influence of heavy responsibilities all around the world. She is related to maternal stress. It is the responsibility of mother to educate her children according to the requirement of contemporary economic and social needs.

"Mother's employment status is also related with child results, it is through the family those effects take place. Outcomes of children are related with mothers' sense of well being and-parenting style.” [4].

Mother education affects her children academics performance irrespective of status, social background, gender gap and other stereotype cast, image and pigeonhole effects. Education eradicates poverty, darkness, deficiency and dearth.

An Educated employed woman in Pakistan not only contributes to the development of economic prosperity of the nation but also greatly serves her families in all aspects of life like, saving of her 
household budget, medical assistance to her parents and in-laws with greater priority. It is a common observation that even an educated employed woman provides shelter, house and other benefits to her husband family with great honor and dignity.

This study was to investigate the role of educated working mothers and educated nonworking mothers in the academic performance of their children at primary level. An employed educated woman has a good social exposure and has rich experiences of modern trends. On the other hand, it is a general perception that educated employed woman is restricted only to earning and her children are ignored, which affects the behavior and performance of her children adversely.

Educated working woman is in a better position to know how to keep balance between her job and family as compared to unemployed educated woman because of economic problems.

This research showed the bond connection of mental health, attitude of child and motherhood behavior to improve academic performance in the light of objectives. The study also explored the interest and struggle of mothers for the education of their children in Swat. There is no significance difference between the academic performance of children of educated employed mothers and educated unemployed mothers.

\section{Delimitation of the Study}

1. The study was delimited to private primary schools of Saidu Sharif, District Swat.

2. The level of education of mothers was F.A/F, Sc and above.

3. The study was also delimited to the students of $5^{\text {th }}$ class in these schools.

\section{Variables of the study}

1. Academic performance of children.

2. Impact of social Interaction of mothers on the academic performance

3. Time management.

4. Economical factors

5. Awareness of mothers for the education of their children.

\section{Research Methodology of the Study}

In research methodology and procedure different steps were involved that are given below systematically

\section{Population of the Study}

Population of the study was all $5^{\text {th }}$ grade students of all primary private schools in Saidu Sharif, District Swat that were 15. The total numbers of students were 358. Mothers and their children of the selected schools were also the part of population.

\section{Sample of the Study}

Stratified random sampling technique was used and one forty students of the total number of students (children) of both educated working and educated non-working mothers were taken as a sample. Besides that, one forty mothers of selected students were the part of the sample. Total numbers of selected mothers were one hundred and forty. Seventy were educated working mothers in addition to seventy educated non-working mothers.

Selection of sample was based on Gay L.R., sample population ratio table, [5]. Total number of 5th class children and their mothers were 280 .

\section{Development of the Research Tool}

All academic results of the selected students, their addresses and phone numbers were collected from the school administration. Questionnaire was designed for data collection. The questionnaire was based on Lickert scale. Questionnaires were handed over to the respondent personally and they were also briefed about the nature of the research.

\section{Data Analysis and Interpretation}

The response received was analyzed through statistical applications using t-test for comparison of educated working mother with educated nonworking mothers in the light of objectives.

\section{Review of Literature}

9.1. Economic and social status of Parents enhanced Children access and quality of Education to achieve the Goal of Universal Primary Education by 2015: Economic and social status enhanced children access and quality of education. the parents' will take interest and send their children to the school with full interest and enthusiasm. Increase enrollment ratio with the help of parent motivation and community involvement "In Pakistan enrollment of girls increased 247 percent in the North West Frontier Province and 197 percent in Baluchistan Province between 1994 and 1998. Student attendance and dropout rates were also positively affected. Each month a five-liter tin of vegetable oil was distributed to the family of each female student who attended school for at least 20 days.” [6]

In the hands of mother in the premises of residential environment, but formal education is in school which may include learning instruction, training, development of disposition, temperament, spirit, mental power through systematic instruction 
and is the successful learning of information, skills and manner". [6]

Manners, methods, etiquettes, behavior are essentials of home parent's like newly born plants in a garden needs care, water, sun rays and other essential ingredients necessary for its growth and development. More than fifty percent population of the human beings comprise of females around the globe: So to protect and shield this larger ratio is in the hand of better environment of economy and equal importance is needed like a man.

[7] "Mother education is the mean of support to sustain the lifelong services of a mother in methods and manners, to polish her children deeds, activities, behavior, academics and performance in education. World education of mothers always help getting better educational opportunities for girls and women develop skills that allow them to make decisions to take action and influence community change in key areas. So all these programs have optimistic force and effect on some of the deepest and important issues of our time, to overcome environmental factors, chemical pollution, population growth, peace and safety, and to minimize gap between the rich and poor, to educate, engage and inspire future generation with great care”.

\subsection{The Value of Parenting and Work} around the Globe. Why the most imperative job in the world is still least valued and consider as harmful for children behavior and learning?[8] According to [8] New studies reject the previous negative images that educated working mother ignore her children and impact of work is negative on children behavior and academic performance. According to [8] University College London researchers studied data collected from 12,000 children and find out that the best plan was everywhere both parents lived at home with their children and worked with management of time. "There is no evidence of ill-effects on children's social and emotional behavior if their mothers work." Anne McMunn investigated that. "some of the findings were partly explained by the fact that mothers who worked were often better educated, in households with higher incomes and were less likely to be depressed." The researchers find that existing studies on the impact of mothers working, particularly in the early years, show "mixed results". Katherine Rake also fined out that, "The fact that no evidence was found to show working mothers restrict the early development of their children is welcome news.

"This study shows what mothers know intuitively if you are able to get the balance right, your child and your career can both flourish." finding of Sally Russell to BBC.
According to [9] "Children are precious and their mothers are the protectors, supervisors and forts of their children. The Price of Motherhood is the most articulates book in a generation. Society should honor, instead of marginalizing mothers".

According to the national survey on $25^{\text {th }}$ anniversary of the working mothers 100 best companies initiative by [10] "challenges still facing working mothers, how mothers feel about their live, career and future generation that more than half of the people on American payrolls are women and moms are the primary or co-breadwinners in almost two thirds of all families. American families are in position to rethink who works, who stays home to care for the kids and who work".

[11] Conducted a national survey that examined mothers in the workplace. What mothers think career and paycheck-working mothers report that firm look at how working mothers are perceived and report from 4600 people across the country show:

- $\quad$ working mothers

- Stay-at-home mothers

- Working dads and singles in the workplace

"The study revealed the attitude and adjustment that have taken place since list debuted. The struggling, rebellious, nurturing and negotiating that happen in homes and in offices are more complex and important than ever because how women in the workplace think and behave is reshaping cultural setting”. [11]

[12] "A new study shows that high-achieving men are more likely to be attracted to successful professionals and working mothers. It defines high achieving as earning in the top $10 \%$ for his age, or holding a graduate degree. Survey reports that $68 \%$ of high-achieving men believe that smart women make better mothers. Smart women mean educated working and productive mothers or in other word smart men marry to smart women to have educated and caring mothers for their children”.

positive effects of mother work and Scheduling Convenient Times "some studies do suggest positive effects of maternal employment on educational involvement, mainly when structural supports such as schools scheduling convenient times for family-related activities are put in place" (Chavkin \& Williams) cited in family Involment. [13] US Department of labor, More than 60\% women in 2005 were busy in working in US Department of Labor, The number number of mothers are increases in contemporary labor force to serve their families."Mothers' involvement in their children's education is one of the family demands that could be negatively impacted by increased maternal employment”.[13]“Despite the positive impact of women on the economy, educators and parents frequently cite parents' busy work schedules as a major obstacle to family 
involvement”. Working mother educational Involment with their children is time demanded for scheduling and rearrangement.

According to the authors [14] "the female work is not recorded in spite of the fact that her work of motherhood as a job is the second largest old profession in the world".

Women in Pakistan were looked up only as the house wives who looked after their husbands and raised their children. All through the centuries, the woman had not been allowed to play her role as an active and equal member of the society. She was as good a human being as the man and had the same sensitivities and capabilities. She could be as productive an agent of the society as man could be. [15]

"Traditional thinking and beliefs are against the employed women that they never good housewives and neglected their children but on the basis of research, it is concluded that employment of women had positive effect on the socio-economic status of the family.” [16]

\subsection{Part-time work contribute to the strength and well-being of families:} Interviews and observation based on more than ten years duration of 1,364 mothers shows that part time working mother are more healthier and less depressive then non working mother. Part time work enhanced well being of children and families. The government and stakeholder should provide fringe benefits, encouragement and education "as part-time work seems to contribute to the strength and well-being of families, it would be beneficial to employers if they provide fringe benefits, at least proportionally, to part-time employees as well as offer them career ladders through” [17]

- training and promotion

- professional status

- $\quad$ scheduling flexibility

- work commitment

- $\quad$ shift schedules.

\subsection{Social and Economical Factors} Affecting Working and Non-Working Mothers. There are different factor having effects on the working mothers. According to [18] "it is known that mothers are not homogenous group of the people. There are no typical working types of mothers. Their attitude towards their jobs and their decision about child care are shaped by range of social and economic factors.”

9.5. Marital status and Family Structure: Statistics indicate that working mothers who are married to the fathers of their children have more stable families. Working mothers, who are single or in non-traditional relationships have a more difficult time in maintaining family stability even apart from the demands of their jobs.

\subsection{Differences between Children of Single family and two families, Employed} and Un-Employed Mothers: The effect of mother work on the father's role to help family to reduce the pigeonhole effect that father is not helping their families in domestic traditional work. Working mother motivate father of her children to participates actively in domestic work and take care of children. "In two-parent families, both sons and daughters of employed mothers felt that men could do the female activities, while those with full-time homemakers did not Subsequent analysis showed that the two parent families, fathers' with employed wives were more active in traditionally female tasks and in childcare. Thus, maternal employment was linked to the less stereotyped view of what men can do because of the effect of mother employment on the father's role and, in the absence of a father, the effect did not occur". [19]. There is a lot shown reasonably consistent differences have examined the relationships within subgroups based on social class and gender. Patterns that have been revealed over the years include the following:

Daughters of employed mothers have been found to have higher academic achievement, greater career success, more nontraditional career choices, and greater occupational commitment.

Studies of children in poverty, in two-parent and single-mother families, found higher cognitive scores for children with employed mothers as well as higher scores on socio-emotional indices.

A few earlier studies found that sons of employed mothers in the middle class showed lower school performance and lower IQ-scores during the grade school. About ten years of age, there were three separate studies that looked at that relationship; two of them found no difference, but the third found lower scores for sons of employed mothers in the middle-class. We found no indication of this in the Michigan study. In fact, we found the opposite in our study, the children of employed mother obtained higher scores on the three achievement tests, for language, reading and math across gender socio-economic status and marital status, middle-class boys included. It was our most robust finding for the child outcome differences. And yes, we controlled on the mother' education. [19].

"Daughters of employed mothers have been found to be more independent, particularly in interaction with their peers in a school setting and to score higher on socio-emotional adjustment measures. Results for sons have been quite mixed and vary with social class and with how old the children were when they were tested. In fact, there was some evidence that those with employed mothers showed more acting-our behavior than the sons of full-time homemakers”. [19] 
"The encouragement of independence and autonomy in girls, on the other hand, would have a positive effect since they are traditionally given too little encouragement for independence”. [20]

"Employed mothers in contrast with full-time homemakers, showed less differentiation between sons and daughters in their discipline style and in their goals for their children”. [20]

"Working mothers as compared to full-time homemakers were more likely to cite independence as a goal for their daughters and less likely to indicate that obedience or to be womanly was their goal”. [20]

\subsection{Common Problems that Educated} Working Mothers Confront. There are many problems which are confronted by the working mothers [21]. They are referred in the following:

9.8. Logistical Problems. “These problems have to do with coordinating the details of the mother's working day, including use of the family care, arranging one's hour's work, dealing with a sick child etc. Nursing mothers who return to work before an infant is weaned often have to make complicated arrangements for expressing and storing breast feed during the working day”. [21]

$>$ Financial Issues

$>$ Professional Development Issues

$>$ Health Issues

$>$ Interpersonal Issues

9.9. Parental Concerns about a Mother's Employment Include Several Long-Term as well as Short-Term Issues. Mother employment is concerned with a number of problems and issues faced by the mothers during the work hours.

[22] Defined the mother's effect in short-term and long-term on the personality of the child. And these issues are concerned with the mother in long and short term as:

$>$ Children's Future Well-being:

$>$ Stability of the Marital Relationship.

$>$ Household Safety and Security:

9.10. Child Academic Performance and ignore jobs of Mothers. The school going children are affected with different problems and issues during their school days that may have effect on the performance of the child.

According to the [23] "Ignore jobs of mother as housewife are in the highest percentage. "up to 70 percent are involved in sowing, cutting wheat and fodder, cotton picking feeding the animals, milking the cows and cleaning the grains in addition to their daily household routines female in construction, woman in sales, mine and quarry workers”..Educated women are in every profession like administration, leadership, lawyers, nurses, doctors, teachers, Office, Welfare. "Parents probably socialize children more by the patterns of interpersonal relations they establish unwittingly than by their deliberate and conscious efforts. At present, the most pronounced social and cultural changes in the structure of family resulting from industrialization and urbanization have altered these patterns of interpersonal relationships. In other words, in the nuclear families of big cities, demonstration of parental behavior patterns indicative of their concern, attention or care for their children has become more challenging.", economical, environmental, normative, resources constrains facing by women in pakistan. [24] "Concluded that full time employed mothers spend less time with their infants and preschoolers than part time and un-employed mothers, but this effect diminishes with maternal education and with the age of the child. In addition, the effect is also less when the nature of the interaction is considered".

\subsection{Different Level of Work and Working}

Mother. Working mother have different mode of work [25], He offers the different working routine regarding time and mode of work as given below:

$>$ Flex Time and Part Time Work

$>$ Mothers Shift Work with Husbands

$>$ Job Sharing

$>$ Telecommuting and Working Mothers

$>$ Self-Employment

9.12. Special attention of Educated Mother to Improve Academic Performance. Educated mother will give special attention to her children suffering from some deficiencies in learning and educating at school. For example in University of New York the five ways of encouraging students according to [26], are to construct confidence and encourage learning in those students who have attention deficit disorder. "

9.13. The Father's Role. In the grooming of the child, a father play important role according to the [26], "Now the father's role has long been viewed as important mediators of the link between the mother's employment status and child outcomes. In addition, although maternal employment was directly related to daughters' views that women are competent in activities generally seen as male activities' higher father involvement increased this effect. In addition, the view that women are competent was a major link to girls' sense of efficacy and test scores. The father's higher 
involvement in child care and the merging of roles there was also related directly to both boy's and girl's test scores".

\subsection{Researches that communicate that Mother Education Affect Children's} Achievement. [33] stated that mother education and employment for social interaction and academic performance is highly countable.

"The non-working woman has more social constraints than working woman, as the working woman is economically independent. Higher education, more training and more earning make strong woman empowerment”. [33]

"The development of learning begins in infancy and extends throughout our lives A child's education must be learner, knowledge, assessment and community centered". It is important and crucial that teacher should involved mother participation for further enhancement of education of her child.[4]

\section{Research Methodology and Procedure}

This study was concerned with the comparison of impact of educated working mothers with that of educated non- working mothers on the academic performance of primary school children. The nature of this research was descriptive. Total numbers of private public schools in Saidu Sharif Swat Pakistan were 15 , the total number of students were
358.

Stratified Random sampling technique was used and one forty students of the total number of students (children) of both educated working and educated non-working mothers were taken as a sample. Besides that, one forty mothers of selected students were the part of the sample. Total numbers of selected mothers were one hundred and forty. The total 70 working mothers and 70 non-working mothers were taken as sample from the total population.

The questionnaire was developed on the five point Lickert Scale. The academic results were collected from the school administration. Questionnaire was handed over to the respondent personally and they were also briefed about the nature of the research.

The data obtained was tabulated, interpreted and analyzed on the basis of t-test and using the SPSS software, [30].The responses received were analyzed through statistical applications, using ttest for comparison of the academic performance of children of educated working mothers and educated non-working mothers in the light of some objectives. (1) to investigate the impact of educated working mother and educated non working on the academic performance of her children. (2) To investigate the perceptions of mothers about her children's academic performance. (3) To compare the academic results of children of working mothers with that of the children of non-working mothers.

Table 1. Comparison of educated working mothers with non-working mothers about monitor the whole activities' of children to increase academic performance of children.

\begin{tabular}{|c|c|c|c|c|c|c|}
\hline Statement & Group & $\mathbf{N}$ & Mean & $\begin{array}{l}\text { Std. } \\
\text { Deviatio } \\
\text { n }\end{array}$ & df & t-value Sig. \\
\hline $\begin{array}{l}\text { You and your husband both } \\
\text { monitor the whole activity of your }\end{array}$ & $\begin{array}{l}\text { Working } \\
\text { Mothers }\end{array}$ & 70 & 3.83 & 1.404 & & \\
\hline $\begin{array}{l}\text { child at home to increase academic } \\
\text { performance. }\end{array}$ & $\begin{array}{l}\text { Non-working } \\
\text { Mothers }\end{array}$ & 70 & 2.80 & 1.509 & 138 & $4.175 \quad .000$ \\
\hline
\end{tabular}

Table No. 1 indicates that t-value (4.175) was significant at 0.05 level of significance. Working mothers had higher mean score (3.83) then non-working mothers (2.80). It was concluded that there was a significant difference between working mothers and nonworking mothers regarding monitoring of the whole activity of their child at home to increase the academic performance of children. 


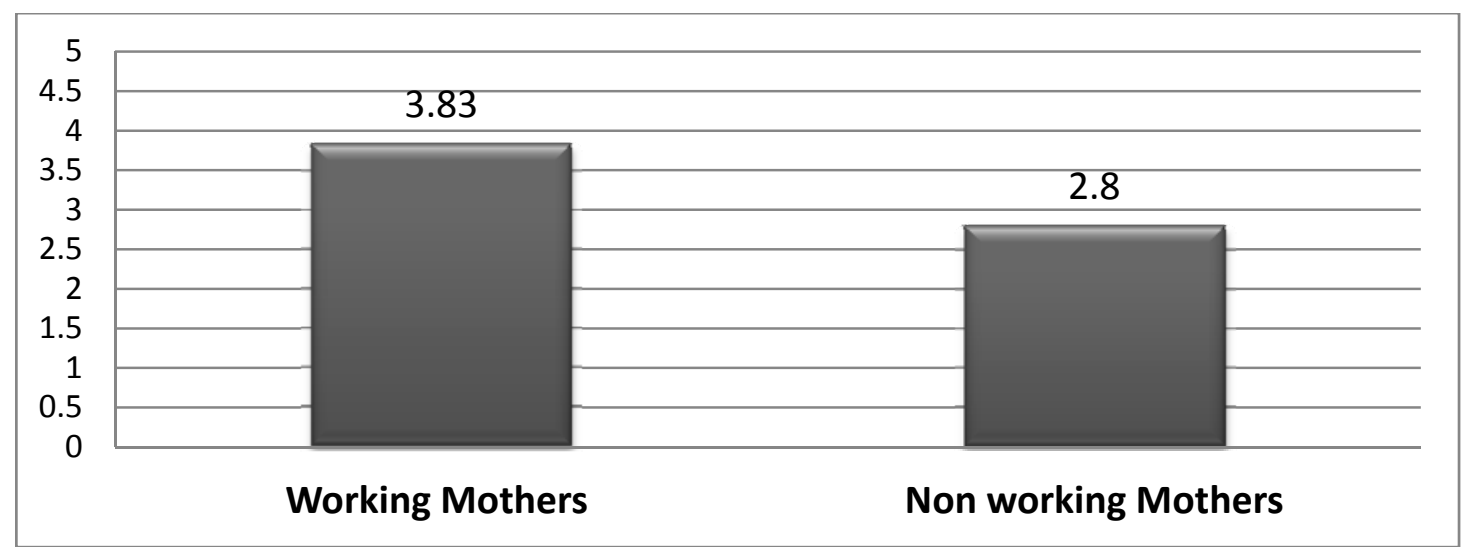

Figure 1. Monitoring activities of children at home

Table 2. Comparison of working mothers with non-working mothers about official timing does not affect education of children

\begin{tabular}{|c|c|c|c|c|c|c|c|}
\hline Statement & Group & $\mathbf{N}$ & Mean & $\begin{array}{c}\text { Std. } \\
\text { Deviation }\end{array}$ & df & t-value & Sig. \\
\hline \multirow{2}{*}{$\begin{array}{l}\text { Your official timing effect on the } \\
\text { education of your children }\end{array}$} & $\begin{array}{l}\text { Working } \\
\text { Mothers }\end{array}$ & 70 & 3.71 & 1.446 & \multirow{2}{*}{$\begin{array}{c}13 \\
8\end{array}$} & \multirow{2}{*}{2.681} & \multirow{2}{*}{.008} \\
\hline & $\begin{array}{l}\text { Non-working } \\
\text { Mothers }\end{array}$ & 70 & 3.01 & 1.637 & & & \\
\hline
\end{tabular}

Table No. 2 indicates that t-value (2.681) was not significant at 0.05 level of significance. Working mothers mean score (3.71) and nonworking mothers mean score (3.01) was almost same. It was concluded that there is no significant difference between working mothers and non-working mothers regarding their official timing effect on the education of their children. The official time does not affect children education due to active management of job and domestic work.

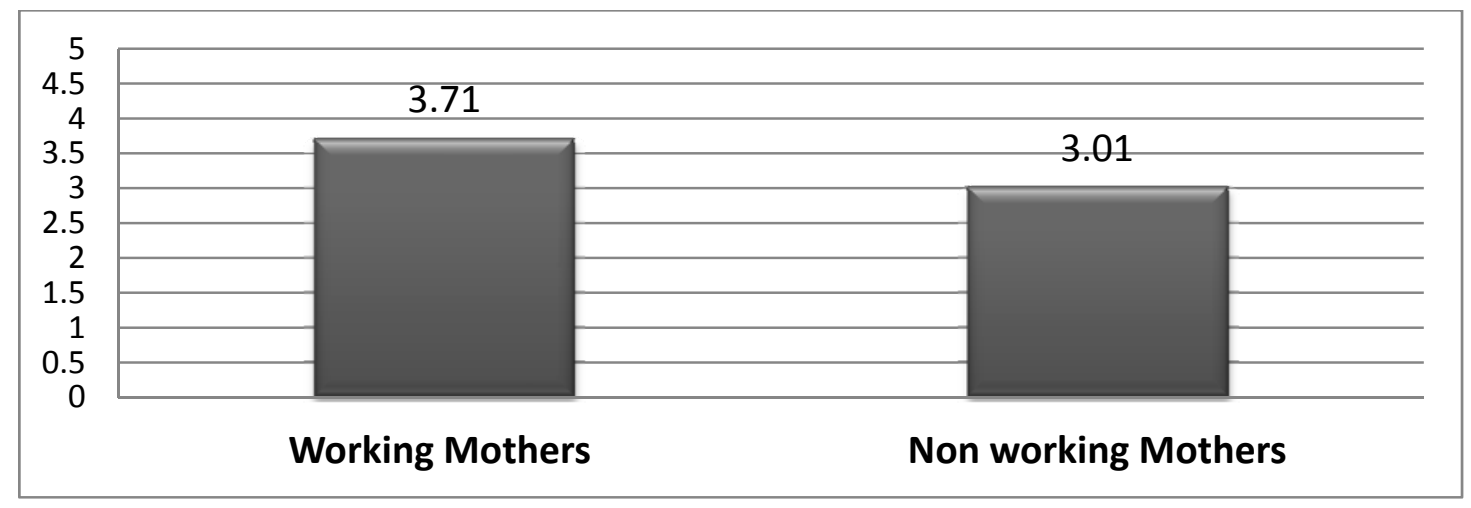

Figure 2. Official Timings that do not affect education.

Figure 3 indicates overall comparisons of all statement given below: 


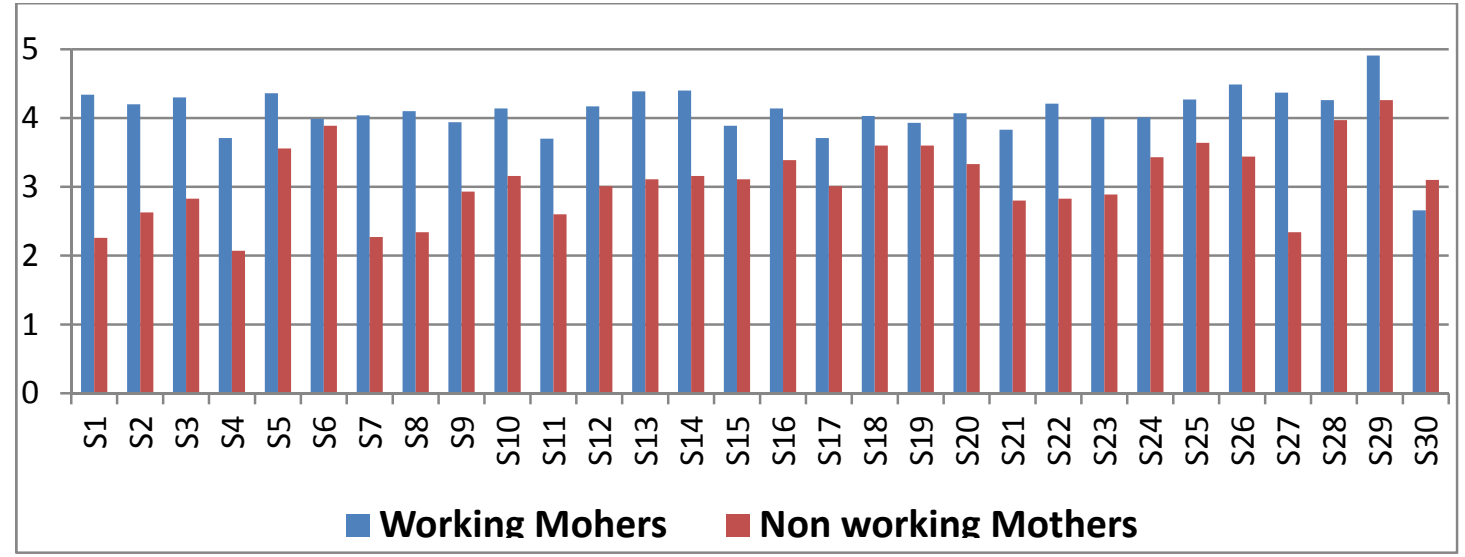

Figure 3. Comparison of Mean score of all statements in questionnaires of educated working mothers and educated non-working mothers

(S1) You attend the entire parent teacher meeting regularly. (S2) Apart from the parent teacher meeting you make contact with the teacher. (S3) Your children generally follow fixed timing for the study, meals and going to bed. (S4) You try to arrange a tutor for your children. (S5)The academic result of your children is getting better every year. (S6) You are satisfied with the academic results of your children. (S7) Your children read story books. (S8) TV is seen at fixe timing by the elder in your home. (S9) Children see all sort of TV program me along with the elders (S10) During the study, you sit with your children (S11) You take the help of your husband or other in the study of your children (S12) You ensured that a balanced diet be eaten by your children (S13) Children should get the best possible education. (S14)You know who your kid's friend is? (S15) Children should not be more than three (S16) Do you think that you face difficulty to handle the problem of your children (S17) Your official timing effect on the education of your children (S18) Do you think you give more time to your children instead of working lady. (S19) Do you feel you have less exposure other than working lady about the new trends of the children education? (S20) Do you think non-working lady provide better education to their children instead of working lady. (S21) You and your husband both monitor the whole activity of your child at home. (S22) You give equal importance to girls and boys education and health. (S23) You give equal importance to girls and boys education to be admitted in same school. (S24)You are more satisfied from girls' academic performance than boys. (S25) Girls are more helpful to mothers than boys. (S26) Do you perform your domestic duties actively? (S27) Do you support your family financially? (S28) Do you feel secure because of your education? (S29) Do you take notice of your child success and failure? (S30) Does education of mother affect academic performance?

\section{Findings}

Table 1 Indicates that t-value (4.175) was significant at 0.05 level of significance. Working mothers had higher mean score (3.83) then non-working mothers (2.80). It was concluded that there was a significant difference between working mothers and nonworking mothers regarding husband and they themselves both monitored the whole activity of their child at home to increase the academic performance of children

Table 2 indicates that t-value (2.681) was not significant at 0.05 level of significance. Working mothers mean score (3.71) and nonworking mothers mean score (3.01) was almost same. It was concluded that there is no significant difference between working mothers and non-working mothers regarding their official timing effect on the education of their children. The official time does not affect children education due to active management of job and domestic work.

\section{Conclusion}

It was concluded that more social interaction and economical assistance of educated working mother make it possible to robust activities and academic performance of primary school children.

Educated working mother is in a better position to manage more effectively a pull to work and to take care of children at home.

according to [32]. Motivation, stimulus and responses are inter link with each other, according to [2] theory. "The non-working woman has more social constrain than working woman, as the working woman is economically independent. Higher education, more training and more earning make strong woman empowerment”. [28] Working 
educated mother is economically independent. "Outcomes of children are related with mothers' sense of well being and-parenting style.” [17] Interviews and observation based on more than ten years duration of 1,364 mothers shows that part time working mothers are healthier and less depressive then non working mothers or stay at home mothers. To sum up the study in the region that socio economical status of educated working mother was directly link with the highest score of their children.

\section{Recommendation}

The following recommendations were made in the light previous researches and data analysis, interpretation and results.

Improved and encourage mother education and work. Help mothers to keep balance between childcare, domestic work and job performance. It is a universal truth that mother is a unit of reproduction and responsible to foster her children. In global village and technological world mother education and work should be highlight by scholars, philosophers and social economist for further research to make contemporary or prospective role model mother in the light of psychological theories.

\section{References}

[1]http://dictionary.reference.com/browse/education Retrieved on 22-January (2011).

[2] Lyn Crage, "Parental education, time in paid work and time with children "British Journal of Sociology 57(4) (C) London School of Economics and Political Science 200( 2006)“,

[3] Munn's, The Evolution and Growth of Human Behavior, New York, Houghton Mifflin, www.igs.net/ pballan/Munn,htm. (1955).

[4] Bransford, J., Brown, A., \& Cocking, RHow People Learn: Brain, Mind, Experience and School.Washington, D.C., National Research Council, National Academy Pressm, (2000).

[5] Gay, L. R., Educational Research, (7 ${ }^{\text {th }}$ ed.), Prentice Hall, Int’l, (1995).

[6] Nancy Birdsall, Ruth Levine, and Amina Ibrahim, building gender equality, toward universal primary education: UN Millennium project of education and gender equality(2006).

[7] Lesler D. C \& Alice C, Human Development and learning, New York, Lyn college, American book company- New York, Department of education Brooklyn college, (1999).
[8] Katherine Rake, McMunn\& Sally Russell, BBC,http://www.bbc.co.uk/news/education14247472,Retrieved on 07/09/2012 BBC,world sevice,Working mothers 'do no harm to children's behaviour,'(22 July 2011).

[9] William, S., Gender differences in pensions, (Women's Work, Wages, and Well-Being: Women's Compensation for Work) Journal of Human Resources, (2011).

[10] Murray, K., Mothers working, United Kingdom, Olivers James Press, (2010).

[11] Ernest and Young, (1975) ,cited in Erenest R. Hilgard, Gordon H. Bowers, Theories of Learning Century Psychology Series, national book foundation, Lahore, pakistan, (2004).

[12] Christine B.W., why smart men marry smart woman. about.com, (2010).

[13] Presidents and Fellows of Harvard College, Published by Harvard Family Research Project http://www.hfrp.org/family-

involvement/publications-resources/making-itwork-low-income-working-mothers-involvementin-their-children-s-education-digest-version, (2012 )

[14] Maqsood, Gender Dimensions of Drop out in Basic Education in Pakistan,

A. www.eurojournals.com/EJSS_24_1_13.pdf, (2005).

[15] Abidi, "Role and status of women in Pakistan, PDF/Adobe Acrobat

Pakistan www.fspublishers.org/jass/pastissues/JASSVOL_1_NO.../22.pdf, (1976).

[16] Azhar, daughters to be in jobs and their effects on female's education and employment, women's education enhances family's social status,Informalisation of Women's Work: www.pide.org.pk/pdf/PDR/1993/Volume4/8 87-893.pdf, (1978).

[17] Cheryl Buehler\& Marion O'Brien, Working Moms Feel Better Than Stay-At-Home Moms, Study Finds, "Science Daily" http://www.sciencedaily.com/releases/2011/12/1112 12124520.htm, (2011).

[18] Baldwin, B., A causal model of the effects of maternal employment on adolescent achievement, Paper presented at the annual meeting of the American Educational Research Association, New Orleans, L, A, (2003).

[19] Gold, Comparisons of adolescent children with employed and nonemployed mothers, MerrillPalmer Quarterly, 24, 75-84, (2008).

[20] Fowler, Maternal Employment in childhood and adults, USA: Retrospectives MIDMAC, Midus wise edu, (2005). 
[21] Etaught, C, Maternal employment Effects on children. In J. Frankel (Ed.), The employed mother and the family context (pp. 68-88). New York: Springer. (1993)

[22] Beyer, The effect of maternal employment on schoolchildren's educational aspirations in Korea findarticles.com/p/articles/mi_hb1439/is_1_15/ai.../ pg_2/, (1995).

[23] Sabeeha Hafeez, The Metropolitan Women in Pakistan Studies, (1981), Karachi press

[24] Desai, S. P., Chase, Mother or market? Effects of maternal employment on the intellectual ability of 4-year old children. Demography, 26, 545-561, (1999).

[25] Chase's, Mothers and children, feminist analyses and personal narratives, - Google Books Result books.google.com.pk/books? isbn=0813528755Chase, (1994).

[26] Kurtz, child learning deficiency syndrome, wwww .child healthe .google .com, (2011).

[27] Nock "maternal employment related to daughters"www.meternal.google.com (1993).

[28] Malik, S.Y., Malik, Impact of Higher Education in Understanding of Social Recognition, Rawalpindi-Pakistan: Institute of Education and Research, Arid Agriculture University, (2005).

[29] Sultana T, employees empowerment and gender differences department of social sciences,,
Hamadard university Karachi press, pakistan, (2002).

[30] Haq, The formal educational system in Pakistan is not capable of meeting the country's growing to meet pressing educational needs and social needs form parent-teacher, www.iizdvv.de/index.php?article_id=1221\&clang=1, (2002).

[31] SPSS, 16, for windows. com

[32] Jean piaget, (1976),cited in Erenest R. Hilgard, Gordon H. Bowers, (2004), Theories of Learning Century Psychology Series, national book foundation, Lahore, pakistan, (2004).

[33] Skinner, (1996), cited in, Erenest R. Hilgard, Gordon H. Bowers, Theories of Learning Century Psychology Series, national book foundation, Lahore, pakistan, (2004).

[34] Hoffman, L.W., "The Effects of the Mother's Employment on the Family and the Child" Emerita, Department of Psychology, University of Michigan Ann Arbor, (1998).

[35] Nancy Birdsall, Ruth Levine, and Amina Ibrahim, (2006), building gender equality, toward universal primary education: UN Millennium project of education and gender equality. 